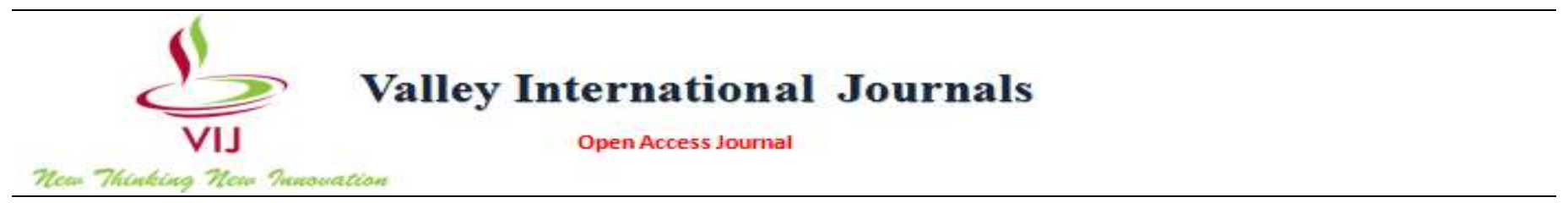

The International Journal of Social Sciences and Humanities Invention

Volume 2 issue 112015 page no.1679-1688 ISSN: 2349-2031

Available Online At: http://valleyinternational.net/index.php/our-jou/theijsshi

\title{
Labor, Emotions And Social Structuration In Argentina
}

Dr. Adrián Scribano ${ }^{1}$, Dra. Gabriela Vergara², Dr. Pedro Lisdero ${ }^{3}$, Dr. Diego Quattrini ${ }^{4}$
${ }^{1}$ Consejo Nacional de Investigaciones Científicas y Técnicas - Instituto de Investigaciones Gino Germani - Universidad de Buenos Aires / Centro de Investigaciones y Estudios Sociológicos
Email: adrianscribano@gmail.com
${ }^{2}$ Consejo Nacional de Investigaciones Científicas y Técnicas -Universidad Nacional de Villa María / Centro de Investigaciones y Estudios Sociológicos
Email: gabivergaramattar@gmail.com

${ }^{3}$ Consejo Nacional de Investigaciones Científicas y Técnicas - Centro de Investigaciones y Estudios sobre Cultura y Sociedad / Centro de Investigaciones y Estudios Sociológicos

Email: pedrolisdero@gmail.com

${ }^{4}$ Consejo Nacional de Investigaciones Científicas y Técnicas - Universidad Nacional de Villa María / Centro de Investigaciones y Estudios Sociológicos

Email: diegoquattrini@gmail.com

\begin{abstract}
This paper sums up - in a cross-sectional perspective - three research studies concerning different work-related experiences in Argentina, involving call centers, social program beneficiaries and urban waste collectors. We discuss a particular dimension of certain processes related to transformations in labor to understand the role of emotions in the current processes of configuration of social relations.

The methodology employed is predominantly qualitative: this paper focuses the analysis on the information gathered through in-depth interviews, from which it offers excerpts of narratives by call-center workers, unemployed trainees at the job training centers and female waste collectors.

From three different perspectives upon the complex labor relations in Argentina - as a possible stage in the current transformation of the labor world - we show how a) socially constructed fear organizes perceptions and structures "correct ways of feeling" to guarantee not only the inexistence of conflict, but enormous profit rates for call centers; b) the “embodiment" of workers' faces is located at the core of a business's presentation, as a human ability to be valued and regulated for social program beneficiaries; and c) the "sensibility of disposable people" displays the way a particular reality becomes unquestionable, favoring a state of occupational disposability, for urban waste collectors.

We state that these changes in the labor world show particular ways of managing emotions, becoming an axis of the "political economy of morals" at the current stage of expansion of capitalist social relationships.
\end{abstract}

Key words: Labor, Emotions, Bodies, Social Structuration, Conflict, Argentina

\section{INTRODUCTION}

Since its beginnings, capitalism has found that sensibility and passions are the key to disciplining and pacifying social relations, through exchange relations, as Montesquieu showed.

This paper sums up - in a cross-sectional perspective three case studies concerning different work-related experiences in Argentina. These studies share a common analytical approach that includes collective action, social conflict, ideological criticism, and the sociology of bodies and emotions (Scribano, 2005, 2010, 2012a). Call center workers in Córdoba city, the beneficiaries of a state program that trains people to get a job in Mendoza, and urban waste collectors from two cities in Córdoba have become paradigmatic examples for the analysis and understanding of the labor world in Latin America. In this region global processes show some particular elements, such as outsourcing from multinational companies, intervention by international organizations through job management programs for "non-productive" sectors, and market expansion towards certain activities that imply new configurations of the notion of commodity (as in urban solid waste recovery).

In this paper we discuss a specific dimension of such processes to show the place of emotions in labor management in Argentina. Our argument then proceeds as follows: first, we present a brief review of the specialized literature to analyze relevant theoretical categories. Then, we explore the experiences of the workers involved in the case 
studies, taking as interpretive nodes the role of the body in their jobs, and how emotions operate in relation to social conflict. Finally, we will emphasize how transformations in the labor world reveal the ways in which the management of emotions has become an axis of the "political economy of morals" at the current stage of the expansion of capitalist social relations.

\section{METHODOLOGY}

It is important to point out that the analysis offered in this article has a flexible methodological structure in relation to the specific characteristics of the diverse job experiences. The methodology we have employed is predominantly qualitative. Phenomena have been analysed, avoiding the socalled "short-sightedness of the visible" (Melucci, 1994), from a critical hermeneutics that deeply explores the senses and meanings of practices. Social agents are the first to know the world, and that knowledge and their affections can be expressed through their discursive awareness, in the sense of Giddens. This is articulated along with an analysis of the social structure to deepen an understanding of the situations and mechanisms at play beyond what agents perceive. In this way, subjective and objective approaches are combined. This has meant the incorporation of variables and quantitative data, bearing in mind that the complementation of quantitative and qualitative methodologies is both feasible and necessary (De Sena, 2012).

Among other techniques, we carried out participant observation (particularly in the case of call-center workers' demonstrations), group interviews (with trainees at job training centers), analysis of periodicals and documents produced by the social actors or state institutions, and indepth interviews. Here we focus the analysis on the information gathered through these interviews, from which we offer excerpts of narratives by call-center workers, unemployed trainees at the job training centers and female waste collectors. In all, sixty in-depth interviews were carried out in the 2003-2013 period in the cities of Mendoza, Las Heras, Guaymallén, Córdoba and San Francisco. A flexible script was applied, which was geared at capturing the motivations, experiences and feelings of workers in detail. The sampling techniques included snowball sampling and intentional sampling. The sample was delimited by adopting the criterion of saturation; that is to say that the sample is delimited when no truly additional information is perceived (Taylor \& Bogdan, 1994). All the interviews were transcribed and analysed in Atlas.ti, applying a thematic analysis that combined deductive and emergent categories.

\section{BACKGROUND}

By looking into reflections and theories about affection, emotions and feelings, we found references to seventeenth, eighteenth and nineteenth century social philosophers, including Descartes, Montesquieu, Bentham, Pascal, La Mettrie, and Darwin, among others. Early sociologists like Comte, Durkheim, Fourier, Marx, Sombart, Simmel and Weber also stated that emotional control is yet another form of discipline, one which affects social practices, relationships and worldviews in a reciprocal and dynamic way (Scribano, 2012a). To a great extent, such concerns are also addressed in contemporary social theory, from different perspectives, by Bourdieu, Giddens, Foucault, Agamben and Esposito. In this context, Brian Turner and David Le Breton have been regarded as forerunners of social studies on the body, including the inquiries about emotions made by Kemper, Hochschild, Scheff, Collins and Illouz (Kemper, 1987; Scheff, 2001).

Nowadays many authors working on the sociology of the body and emotions take part in a heterogeneous plexus, putting different emphasis on the relations between natureculture, naturalism-constructivism, and positivisminterpretivism.

There are also different ways of systematizing those approaches. Some classify analytical perspectives in terms of naturalism and radical/non-radical constructivism (Armon Jones, 1986; Hochschild, 1990), while others distinguish between determinism, constructivism and interactionism (Smith \& Schneider, 2009), arguing that there are models of emotions, such as the basic model, appraisal model, psychological construction model and social construction model, that generate or regulate emotions (Gross \& Feldman Barrett, 2011).

Such contributions reinforce the interest in those emotions that are interwoven in and with bodies - to understand the social processes underlying the naturalization of the conditions of social (re)production - and adjusted to global changes in the labor world, showing specific differences in the Global South (Lisdero, 2010; Lisdero \& Vergara, 2010; Scribano, 2012b).

This work is based on the assumption that said transformations are characterized by the transnationalization of the Latin American economies (Katz, 2001), the redefinition and implications of the changes in the constitution of the "class-that-earns-a-living-out-of-work" (Antunes, 2005), as well as variations in the technological patterns and order as renewed manners of the social organization of work. Besides, in Latin America, the notions of "typical" and "not classic" jobs are being challenged with a view to problematizing phenomena such as working at home, the production of symbols in design areas and a variety of experiences associated with "immaterial" production (De la Garza Toledo, 2009).

In this context, we therefore state that the management of emotions and changes in the labor world are deeply interrelated.

Some details are provided below in relation to our case studies, including (a) current issues in call centers, (b) competencies related to state programs and (c) work experiences of urban waste collectors.

(a) Some authors think that call centers have become a paradigmatic area in which to analyze current work transformations. Montes Cató (2006) summarizes some research about "psychological" and "emotional" content, such as the efforts to qualify the features of workers' vitality at work (Mulholland, 2002). He also makes the distinction between research studies that emphasize the communicative act as an intangible product and one that flows naturally from work, and those studies that highlight the differences 
between repetitive-mechanical tasks and emotional management tasks (Callaghan \& Thompson, 2000; Glucksman, 2004). In addition, Braga (2009) suggests a complementary approach to call centers as a potential sector for analysis. In Latin America, the studies by Micheli (2007) and Montarcé (2011) are outstanding contributions to our understanding of the complexity of this phenomenon.

In Argentina, Del Bono (2010) analyzes the impact of transformations in the production processes upon labor relationships, and work organization and content. Regarding conflict analysis, Abal Medina (2010) explains the methods of politicization deployed as strategies for resistance, while describing "offshore call centers" as a specific device for exploitation. Del Bono and Henry (2008) look into the strategies used by outsourced/offshore companies and their connection with labor unions, which are not truly representing the interest of their members over the flexibility in labor markets in relation to offshoring and outsourcing.

(b) Even though the point of departure for studies about "workers' knowledge" and qualifications can be traced back to the Scientific Management theory spearheaded by Taylor and Ford, the thorough criticisms of Taylor's processes and management (as well as of the unskilled labor it generated due to mechanization and automation) made by Harry Braverman (1974) became a milestone. In the 1980s, Coriat (1981) analyzed the reinforcement of a new paradigm in the production system applied by Toyota, as Taylor's model was becoming obsolete and new soft technologies were being promoted. Job qualification would then result from a set of behavioral competencies needed to do a job; thus, some experts have replaced it with the notion of competence (Carrillo \& Iranzo, 2003). Discussion of this "new qualification" in Latin America related mainly to the international context, due to pragmatist ideas from the business sector and policy-makers that focused on the link between production and professional training (Cinterfor, 1996; Gallard \& Jacinto, 1995).

(c) Studies that place waste recovery in a macroeconomic context consider the emergence of waste pickers to be a consequence of neoliberal policies that have brought about unemployment and marginalization. Yet, despite their expulsion, waste collectors manage to find informal jobs and improve on their income through cooperatives (Fajn, 2002). A critical look at this matter proposes conceiving waste collectors not as excluded or marginal workers but as parts of a fraction of the displaced working class that constitutes a reservoir of relative overpopulation. This does not amount to their expulsion; on the contrary, because they get paid by the job, they are a cheap productive work force (Villanova, 2012). Studies of subjectivities view emotions as expressions of values; from their viewpoint shame is interpreted as turning up when there are swift changes of direction in the career path, and as expressing values and incomplete projects. The naturalization of work, favored by the individualist influence of neoliberalism, has contributed to transform that shame into a sense of pride that derives from having created a job and not making a living by stealing (Perelman, 2014).
In order to draw an analytical axis that crosscuts the three case studies, we take a sociological perspective on bodies and emotions in the context of present-day capitalism. This approach is structured in relation to a set of categories that we set out in the following paragraphs.

We assume that there is a connection between the structures of dependent and neocolonial capitalism (Scribano, 2012b), and the configuration of certain experiences and sensibilities. The metamorphosis of work in a globalized capitalist system - characterized by appropriation, exploitation, and recycling of bodily and social energies involves and interacts with at least three factors: the depletion of goods as a sign of the expansion of capitalism, modifications in key features of expropriation, together with the management of production and consumption through the politics of emotions.

The structure of the procedures and of the praxis of capitalism in its neocolonial stage, in dependent systems, can be summarized in the requirement for subjects to become a commodity, which results in, from and through the body as a locus of conflict and order, and as topos of several contemporary antagonisms.

In the dialecticized links between expropriation-plundering on the one hand, and clotting-liquefaction on the other hand, we observe two instances of conflict avoidance elaborated by capital: social bearability mechanisms and devices for the regulation of sensations (Scribano, 2007a; Scribano \& Lisdero, 2009). The former are structured around embodied [1] practices aimed at systematically avoiding social conflict. In so doing, displacements of the results of such antagonisms look like specular situations disconnected from time/space, building consent on the certainty that social life is always-like-that. By avoiding, omitting or putting aside the causes and effects of such conflicts, it is easier to reach that consent.

In the labor world, some bearability mechanisms are also identified as mediators that turn those excluded from the late 20 th century into those disposable resources in the $21 \mathrm{st}$ century. Transformations in the labor world not only bring about "new" management and association strategies (Lisdero \& Quattrini, 2013), but also activate mechanisms to diminish the disruptive potential of conflict situations and the collective action related to them (Lisdero \& Vergara, 2010).

Yet social agents get to know the world through their bodies, where perceptions, feelings and emotions converge to build their sensibilities. The management of emotions is directed by the regulation/deregulation of a certain politics of emotions that eventually gives shape to a political economy of morals. To identify, to produce and to reproduce an emotional plexus that indicates how to name and feel the world in certain ways (and not otherwise) constitute a set of ideological practices that become systematic in such a political economy of morals.

Besides, we can assert that existing domination systems established between distances set in and through particular body geometries - allow for (a) inertia patterns of the bodies; (b) their potential displacement; (c) their social evaluations; and (d) types of socially approved uses. 
Domination is not executed over the body at all times/in all spaces on a regular basis. Bodily marks appear as socially established inscriptions made by the domination processes in which a society is immersed. In other words, body geometry is based on a geoculture and geopolitics of domination. Therefore body politics, that is, those socially convened strategies to assure social availability of individuals are just a chapter, not yet a minor one, of power structuration. Such strategies are related and 'reinforced' by a politics of emotions aimed at regulating the construction of social sensibility.

When conflict situations are taken as natural, get neutralized or blocked, or even get displaced or reversed, they operate as (dis)connections between causes and consequences of such oppositions, so conflict is experienced through a weave of emotions that is part of cognitive-affective patterns and chains related to social practices and worldviews that have been embodied [1]. These ideological processes become a practical and procedural link to bearability mechanisms, working on the surface of common practice, in the folds of common sense, and in the construction of apparently intimate sensations.

Below, we analyze these case studies by focusing on the interrelation between bodies and emotions at work.

\section{FINDINGS. WORK IN ARGENTINA NOWADAYS: AN ANALYSIS OF THREE CASE STUDIES}

In this section we analyze three different case studies that show how capitalism encourages the development of work as a key instance to manage emotions by avoiding conflicts, naturalizing its daily coexistence and embodying its consequences.

\section{A. Call centers: emotions and a new materiality of work}

Changes in the relationship between surplus value and wage labor can be analyzed in the context of call centers, which are conceived as "the platform developed by companies to meet specific client demands remotely. They are telephone platforms that can be directly managed by the company that provides customer services or by outsourcing companies in charge of this service" [2] (Del Bono \& Bulloni, 2008: 3). In fact, the expansion of this activity at a global level is related to increasing outsourcing trends started by transnational companies, which have been subcontracting work processes since the ' 70 s to reduce production costs. In Latin America, an estimated 675,000 people are working on this field in Brazil (Oliveira, 2009) and 380,000 in Mexico (Montarcé, 2011).

In Argentina, this "industry" has rapidly increased since 2002, when domestic currency was devalued, resulting in a reduction in labor costs (this activity was defined by the Collective Labor Agreement as a commercial business, which implied an additional reduction in comparison to phone companies staff) and in the monopoly of multinational companies that mainly provide export services. Fewer than ten companies run the business today and no more than six are in charge of exports exclusively (Del Bono, 2010). About 60,000 workers are employed in this sector, mainly located in Buenos Aires, Rosario, Mendoza and Córdoba. According to experts, these cities offer a great employment niche due to the high availability of young professionals or undergraduates. Moreover, state governments have granted tax exemptions to these companies, as well assome privileges encouraged by the national government.

The case of the city of Córdoba is paradigmatic. First, the sheer magnitude of this activity in one of the main and historic industrial areas of the country reveals the qualitative and quantitative changes that have taken place in the world of labor: around 20,000 people work at call centers. This expansion has become part of the agenda in state-funded programs, which offer benefits such as tax exemption (Decree 682-2002; Law 9232-2005). Besides this, an organization has been established in the city specifically for the companies in this sector of the economy (the Board of Companies that provide Contact Services for Third Parties in the Province of Córdoba - C.E.S.C.T. is the Spanish acronym), which, along with other organizations of companies, managed to push for a Collective Labor Agreement to regulate the activity (Lisdero, 2010).

In the context of the expansion of this sector, two significant features of call center workers' experience become relevant in order to emphasize the connections between transformations in work and the place of the body/emotions in those processes. Those features can be laid out on the basis of the connection between immateriality and the body on the one hand, and the links between emotion and processes of expropriation on the other.

1)Bodies as a focus of analysis at "smokeless industries": the place of emotions in expropriation processes: Call centers constitute a representative place to inquire into the transformations of the "materiality" of the bodies that are set up in new labor scenarios. As the process of digestion requires a stomach, the availability of energies for expropriation and the use of the productive system to generate surplus value (and so reactivating mechanisms to favor the expansion of capitalism) requires the existence of a biological-organic body.

Apparently, the expansion of call centers and the promises of their labor model [3] have challenged those ideas related to material living conditions and work; as such a model is often regarded as an effortless activity (where subjects do not even have to think, as conversations follow a preestablished script). Even when it seemed that the subject had been liberated from "earning their daily bread by the sweat of their brow" and that bodies were no longer essential in surplus value production, a new working process linked to the expropriation of living energies from and in bodies has arisen. Body absence in the apparently non-material attribute of these "new jobs" actually indicates the redefinition of material body presence.

In this sense, the social and historical construction of a body's available energetic quantum is associated with the expropriation of a certain operative capacity of the social being. The expropriation and plundering of energies become processes related to the clotting and the liquefaction of social action. In other words, such actions turn into 
mechanisms (Scribano, 2007b) that are embodied by/in workers, who adapt themselves to daily and heterogeneous work scenarios, forgetting their "autonomy".

To identify these mechanisms, the analysis of conflict in this sector of the economy reveals the deployment of diverse social emotions whose result is the naturalization/reproduction of conditions of expropriation. For example, an outstanding feature is how recurrent the sense of fear is in this "new" labor scenario, and how it is related to some processes to avoid conflict:

The thing is that maybe we are always afraid, we don't demand what is right for ourselves... Or maybe we don't have any initiative, don't get informed, so we just get used to this, and we go on and on just like that... (EL 11, Córdoba, 2009).

Fear is defined in a synergetic articulation with a set of complementary sensations that perform the capacity for action, and constitutes workers' naturalized experiences. It originates in the incorporation of accepted ways of managing bodily energies, and it operates through the organization of perceptions that shape sensations like threat, impotence, extortion and an inability to get disconnected (to break the expropriation destiny). Threats are experienced not only during protests - where workers go into street demonstrations wearing masks to avoid being identified but also in daily work relations, in which workers are monitored by permanent recording of their communications. This sensation reinforces the sensibility that makes them feel paralyzed. The masks take the place of what cannot be shown, that is, what is daily built as invisible: "other-faces" of workers that allow them to be recognized as such; "othermovements" that would allow them to break up the daily silence upon which this disturbing silence is structured; "other-ways" of feeling to dismiss fear as the "only possible destiny". Permanent connection and continuous threat guarantee an omnipresent fear. The headset [4] represents the silence emerging from a way of connection, established by certain social relationships that only allow for the client/company's voice.

Fear is then socially constructed to organize perceptions and to structure the "correct ways of feeling", so as to guarantee both the inexistence of conflict and huge profit rates for this industry, which keeps growing in the absence of any challenging voices.

Regarding the paradigmatic case of the expansion of call centers, featured as a bodily expropriation experience, we observe the complex relation between social emotions (such as fear) and the bearability of expropriation conditions. In our view, the transformations of the labor world can be observed in two of its basic components: the redefinition of the place the body occupies in the reconfiguration of the "immateriality" of the productive process, and the centrality of the construction of a particular sensibility as a possible condition for the "re-invention" of expropriation mechanisms.

\section{B. Competencies for normalizing the workforce}

Another interesting way to understand the changes in the management of the workforce in contemporary capitalism and the relationship between the processes of configuration of ideological mechanisms is to look into the knowledge that is put into play in the policies of work training directed at people who work for a living.

In this sense, we proceed to describe these policies as one of many mediation networks, developed from the paradigm of competencies and suggestions training as a means of inclusion into the labor market. In particular, we will analyze those geared at subjects that have a minimum availability of energy for (re)production: the unemployed. As many other energy administration policies prompted by the expansion of capitalism, these do not only intend to bring value back to apparently surplus bodies (which would not be taken as commodities any longer), but are also part of the machinery of devices that regulate sensations.

In certain sectors of the economy, the system of work competencies led to the introduction of new criteria for managing the workforce. Several agencies began to promote a business training methodology that was consolidated in various fields of learning.

This new business logic first operated upon workers' abilities in the most modern productive activities, but it then achieved diffusion and expanded in other areas. One of the reasons for this was pressure from international organizations, experts and some influential productive sectors, interested in promoting reform of the educational system and work management.

Important advocates in the region are CINTERFOR (the Spanish acronym for Centro Interamericano de Formación Profesional, Inter-American Centre for Knowledge Development in Vocational Training), a technical service of the ILO (International Labor Organization). In order to contribute to the dissemination of this paradigm of competencies, these institutions, in cooperation with the Ministries of Education and Labor from countries in the Southern Cone, have carried out several studies to strengthen its development and its theoretical and methodological bases. It is noticeable how the implementation and certification systems encouraged in different productive sectors and the creation of competencies training programs in formal education have been supported (Riquelme \& Herger, 2007:15).

CINTEFOR worked in Argentina on the Programa de Certificación Laboral de Competencias (Labor Competencies Certification Program, 2004-2008), which puts forward the creation of the National Certification System. During this period, about 180 norms for labor competencies were established; 15,000 workers were assessed (though only 12,000 obtained their certification), and 21 organizations for industry certification were created, including 30 working sectors such as automotive, construction, metallurgical and textile industry, among others (Figari \& Alvarez Newman, 2011).

In addition, a series of procedural manuals were developed in the domain of public policies - all related to the system of labor competencies - to train the workforce via employability problems. Most Latin American countries have implemented several programs aimed at improving 
social and educational conditions. In Argentina, the program Jóvenes Más y Mejor Trabajo (hence forth PJMyMT; "More Youth and Better Jobs") was introduced at the national level in 2008 by labor state agencies in local councils (ProgramaOIT, 2011:50). This training program was directed at eighteen- to twenty-four-year-olds who had not completed primary or high school and who were currently unemployed. The main goal was to carry out a set of actions to promote “continuous training". By 2012, about 400,000 people had already participated as beneficiaries in this program throughout Argentina.

1)The imprint of competencies on job training: Competencies appear to be a mixture of operative abilities related to different workers' practices, representations or cognitive-bodily-emotional techniques, which get entangled and become complex as they are mobilized and made flesh by bodily performance. As they are set and managed, they turn into a process that takes place during subjects' lives during their daily, educational and working experiences. The singularity of such a system lies in the individuation of certain workers' attributes, career paths and characteristics. Workers are the protagonists; in their active role (regarding their responsibilities, living energies and capacity for intervention), they recognize and ratify any adequate and effective knowledge. Another characteristic of the model is the distinction and incorporation of "attitudinal knowledge" or "knowing how to be" into the knowledge applied to the job. This refers to attitudes, aptitude and behaviors that are socially required for a specific job. The organizational model values the sensibilities and abilities for bodily/emotional management. The body, its image and its impressions emerge as a field of mutual perception in the interaction that takes place at work, and it is committed to showing basic behavioral elements (incorporated in its materiality, such as mood or bodily orientation, among others).

To illustrate, we take into account the suggestions and assessments made by technicians at PJMyMT about those personal abilities that young people should develop when introducing themselves in the labor market, like the narrative by one of the young beneficiaries about their experience in a job interview:

Employers get the impression of a careless worker when they come in wearing a hood [5]. Sometimes there's a lot of prejudice. It happens to be a neurological aspect, the first impression you get of a new person creates a fixed mental image. So, when people come in wearing hoods, or they just sit down and don't look you in the eyes, employers don't trust them at all. (EQ4, Las Heras, 2013).

Good personal appearance requires at least being neatly shaven as a sign of respect, with a tidy hairstyle and wearing the right outfit, like a pair of jeans or slacks and a shirt. You don't need to wear a suit, but have to shower. (EQ9, Las Heras, 2013).

I was taught to speak well, stand up straight, to look people in the eye. To say "good morning", to sit where you're asked to do so. To deal with tension... to look at the employer. That was good, because when I had my interview I felt confident. And the employer walked around the office and I followed him with my eyes. (EQ15. Capital-Mendoza, 2013).

These interviews show the bodily and emotional management that are demanded of youths in order that they acquire the ability to "introduce themselves to society". Such abilities are constructed in terms of "socially convened perceptions", that is, based on employers' stereotypes, which are even reproduced by the program's technicians. These impressions work as principles of organization and structuring for representations and cognitive techniques that "bodily discredited" people must put into practice to grab an opportunity in the job market.

Even though "good personal appearance" is often institutionalized upon the origin of expectations related to the meaning of specific tasks, it is possible to claim that there are general looks and demeanors that are required by jobs. The practical use of bodies in the sense of "body image" and "construer of senses for the other" becomes a source of value which is classified and regarded as an important element of the workforce, as other kinds of knowledge. The interviewed subjects point out that the right outfit, looking tidy and being showered (without body odor) are essential; and above all, they highlight personality traits such as shyness and having good communicative competence. To avoid being marginalized, that is, "to build trust", the worker's body should adopt a "correct image and demeanor", which also implies reproducing certain sensations and feelings, as can be seen in the narrative by the young subject that was interviewed.

According to Goffman (1970), we can observe how these elements are confirmed by somehow displaying young people's faces. The socially competent individual is "the one that is shaven", "the one that has a tidy hairstyle", "the one that takes a shower", "the one that maintains eye contact", while the candidates that are disqualified for the job do not show their face, look down and hide under a hood. The assessment of a person's appearance is predominantly made during the "first three minutes" of a face-to-face interaction, at which time most stereotypes and social prejudices are reproduced. Therefore, the face produces an immediate emotional reaction, inspiring confidence or posing a threat, and so do ways of looking and bodily movements. The adoption of a normalized bodily dialect can only be achieved by getting used to experiencing the pressures of the labor world, through getting closer to the expectations at play in the interactional scene.

The display of the face becomes a basic and exclusive requirement in the job market. The existence of such competence indicates how the body is located at the core of a business's presentation (in its material and symbolic sense, while embodied in the worker's face), as a human ability to be valued and regulated. In this sense, human survival is associated with the ability to acquire "goodlooking/attractive energies" to avoid being discarded as a commodity in market exchanges.

C. Work, waste and sensibilities 
Call center workers have to adjust to the demands of a job that appropriates their bodies and emotions. The unemployed have to normalize their bodies in order to obtain the capacity for employability. In this section, we describe the experiences of those subjects that work with waste, to show the relationship between sensibilities and bearability.

In Latin America solid waste recovery has become an occupation for those who are not employed in the formal sector, who belong to lower socioeconomic groups and who earn a minimum income for subsistence. Although the activity boomed in Argentina after the 2001 crisis, it has not yet declined and is part of the "waste business", from which waste collectors (men, women and children) barely get a small share of the profits. This informal activity is carried out in different ways: first by picking up waste on the streets or dumping sites, and then selling it to other waste collectors that later deliver waste to factories or storage sites. Recyclable materials including cardboard, PET, paper, glass and plastic are sold by weight. Despite the setting up of workers' cooperatives, this activity is still an emblem of urban poverty and exclusion in Latin America, showing an intense mechanism of surplus value. Such a process requires physical work to retrieve non-valuable objects, which have been thrown away after consumption and now return to the formal economy and the industrial sector at the expense of collectors' social exclusion.

Recycling waste involves a bottom-up configuration of the world based on the position of the body looking down on the ground, crouching down to pick up cardboard and bottles.

As time goes by, collectors' eyes and hands become trained to easily identify the content of waste bags. They go around the city using different perception patterns; for example downtown [6] is not perceived as a place for entertainment or shopping but as a high concentration of waste.

The body, practices and perceptions interplay with ways of feeling: there is a sense of shame when people look at them with mistrustful eyes; anger when stores do not give them cardboard; or even happiness when they make a "good sale". At interclass encounters, where class differences are reproduced as well, there are feelings of self-blame, helplessness, despair, fear, anger and tension. The emotions and perceptions making up the experiences of waste collectors have been previously categorized as the sensibility of disposable people (Vergara, 2012). Their practices make reality unquestionable, favoring a state of "occupational disposability", which involves being available for waste, turning themselves into grime, receiving what others throw away, wearing worn-out clothes, eating leftovers. It is possible to identify this sensibility in the streets where female collectors earn a living from urban waste.

1)To live on what others throw away: On the streets, female collectors distinguish between those who can give objects away because they have too many and those who, like themselves, survive on leftovers. This is observed in the difference between giving and throwing away. Giving involves brief face-to-face encounters in which collectors are given clothes, food and electrical appliances with a caring attitude. Throwing away involves people getting rid of objects they deem to be waste with no value or use. In the latter case, female collectors have a face-to-face encounter with the objects or commodities:

T.: I make a living out of waste. You throw away a piece of paper and I collect it for sale. My money comes from that. I live on waste. (EV8; Córdoba, 2008).

"Disposability" becomes a particular way of experiencing the world, which is embodied through certain bodily postures and daily practices, such as crouching down to pick up paper thrown away by others, collecting and then selling it. In this specific action of picking something up, there is a body, with its physical energy, its emotions and its perceptions that naturalize daily life. Because of this practice, waste becomes a commodity again.

"Living out of what others throw away" goes deep into different bodily dimensions, shaping emotions and perceptions that modify the limits of repugnance and shame as time goes by. This shows the naturalized acceptance of structural inequalities, different abilities to appropriate the world, and a willingness to be available for objects. Daily life is then tied to waste, which is sometimes even more important than life itself, already "discarded" by structural poverty:

C.: If you know you can give a life to someone else, put it [cardboard] aside, if you know they can sell it... that's what I think, I don't know, but many others don't think that way, y'know? (EV3; San Francisco, 2008)

Discarded bodies make a living out of waste, but other people do not "see" that cardboard on the streets can "give life". The interviewee complains about others people's behavior as they seem to overlook, ignore, or reject their situation. If they take cardboard out on the streets when it is raining or throw it away with leftovers, collectors cannot reuse those materials for sale.

Even though objects can return to the circuit of the formal economy, subjects/social actors/agents/people remain expelled. On the other hand, if cardboard "gives a life" to people, the opposite relation gets blurred and blocked: cardboard get back to life as a commodity at the expense of the physical energies used by women, men and children for picking up, carrying and storing it.

2) Waste and emotions at stake: Waste recycling involves specific bodily postures and a dialectical relationship between perceptions and emotions. This makes it easier to receive other objects that are obtained along with cardboard or food:

I.: ...then [a person] came out of the house saying "don't leave, I'll give you a radio" - he says - a radio like this big - he says - "for years, for 30 years I've had it" (?) but it's like new, new[.] (EV1, San Francisco, 2008).

The symbolic and economic value of many objects increases as time goes by. Antiques such as cars and stamps are the 
opposite end of what we have described thus far. This radio, used for 30 years, turns into a "new" object because of its new owner. Such a transition, which involves the joy of receiving an object, is combined with perceptions that aesthetically renew the object, so it can be used for the "first time" by somebody else, another disposable body (it is usual among collectors to "see" money where others only see waste). The blurred limit between used and new operates as a mask, where earning a living out of what other people do not use any more becomes habitual as well as pleasant, rewarding and reassuring.

The practices and emotions of women that recycle waste enable us to identify a specific sensibility: it is possible to live on what others throw away, when their bodies get accustomed to seeing the world from below, when they perceive that their survival depends on what other people have in excess, on what others throw away. This sensibility - despite how specific this occupation is - has similarities with the other two cases: it facilitates conflict avoidance, naturalizes inequalities and involves bodies/emotions as the locus of domination.

\section{CONCLUSION}

Throughout this paper we have analyzed certain situations that approximate/differentiate the interpretations about emotional coercion by Elías, emotional labor by Hochschild, or frozen emotions and their marketization by Illouz.

We have pointed out how conflict avoidance, the naturalization of its coexistence and the act of embodying its consequences become central features of the management of emotions in the unnoticed embodiment of a political economy of morals.

We have summarized in our inquiries how central features of bearability in the expropriation of energies are exhibited by new forms of work (call centers), training policies (competencies) and the picking up of waste. All those who work in communication services in the formal sector, or who look for a job, or who collect waste on the streets, "take part" in the huge efforts made to naturalize a specific political economy of morals within capitalism.

From three different perspectives upon complex labor relations in Argentina, as a possible stage in the current transformations of the labor world, we have shown how (a) socially constructed fear organizes perceptions and structures correct ways of feeling to secure not only the inexistence of conflict, but huge profit rates for an industry that keeps growing without any questioning; (b) the embodiment of workers' faces is located in the core of a business's presentation as a human ability to be valued and regulated; and (c) the sensibility of disposable people displays the way a particular reality becomes unquestionable, favoring a state of occupational disposability.

We have also stated that capitalism can be understood by looking into the management of emotions as a cornerstone of a political economy of morals. This management operates as a mediation upon which the politics of emotions organize (social) practices as follows: a) Smiles are regulated because the subjects' most "intimate" words, feelings and capacities are thoroughly intervened into, just as their capacity to "say-somethingdifferent (about-themselves or for-themselves)".

b) Good personal appearance is requested as a "first impression" competence to stick to principles of organization, structuring of representations and cognitive techniques that bodily discredited people must put into practice to grab any opportunity in the job market.

c) Uncertainty and scarcity teach how the action of throwing away is a particular form of feeling the world, which is embodied on the basis of certain positions and everyday practices.

"Smile, we're watching you" and "Be alert, you'll be made redundant sooner or later" are ideological practices that "embody" - in a conflictive, complex and indefinite way - a specific management of emotions that shapes a partial image of the current labor world in Argentina by means of interrelations and disconnections.

In this paper we have analyzed the management of emotions in three regulated scenarios that serve as a metonymic set of the components of the politics of emotions in Argentina.

As initially stated, we have provided some arguments to look into the critical role of emotions in labor management, also showing that the management of emotions as a cornerstone of capitalism is a key axis in the process of expropriation of workers in Argentina.

\section{ENDS NOTES}

[1] We use the term "embodiment" in a sense that is different from that developed by Csordas (1990). In its place, we would like to emphasize those dimensions of the expression that are linked to the notions of made flesh or made body.

\section{[2] Our translation.}

[3] The concept of model refers to a management lab and an assessment dimension spread by different business and government sectors that consider this industry a "successful model" for public and private management of unemployment. Cf. Lisdero \& Quattrini (2013).

[4] A technological device used by call center workers to take and make phone calls.

[5] A loose covering made of cloth for the head and neck, often attached to a robe or jacket.

[6] The downtown area of the cities where fieldwork was carried out is characterized by a high concentration of clothes shops, banks, restaurants and coffee houses among other businesses. It is a space designed aesthetically for consumption. Going through or living in that area requires economic, social and cultural resources. Given the agglomeration of shops, a great amount of solid waste is generated. 


\section{REFERENCES}

[1] Abal Medina, P. (2010). Modos de politización de organizaciones de trabajadores en grandes empresas. Estudios Sociológicos, vol. XXVIII, núm. 82, 41-65. Retrieved from http://www.redalyc.org/articulo.oa?id=59820675002ER

[2] Antunes, R. (2005). Los sentidos del trabajo. Ensayos sobre la afirmación y la negación del trabajo. Buenos Aires, Argentina: Ediciones Herramienta y TEL.

[3] Armon Jones, C. (1986). The thesis of Constructionism. In R. Harré (ed.) The social construction of Emotions (32-56). New York, U.S.A.: Oxford/BasilBlackwell.

[4] Braga, R. (2009). A vigança de Braverman: o infotaylorismo como contratempo. In R. Antunes, and R. Braga (ed.). Infoproletários. Degradaçao real do trabalho virtual (59-88). São Paulo, Brasil: Boitempo.

[5] Braverman, H. (1974). El trabajo y el capital monopolista. Ciudad de México, México: NuestroTiempo.

[6] Callaghan, G. and Thompson, P. (2002). We recruit attitude: the selection and shaping of routine call centre labour. Journal of Management Studies, 39, 233-254. DOI: $10.1111 / 1467-6486.00290$

[7] Carrillo, J. and Iranzo, C. (2003). Calificación y competencias laborales en América Latina. En E. De la Garza Toledo (Ed.), Tratado Latinoamericano de Sociología del Trabajo (179-212 ). Ciudad de México, México: El COLMEX,FLACSO, EAM, FCE.

[8] Coriat, B. (1981). El taller y el cronometro. Ciudad de México, México: Siglo XXI.

[9] Csordas, T. (1990). Embodiment as a Paradigm for Anthropology. Ethos, Vol. 18, No. 1 (Mar., 1990), 5-47. Retrieved from: http://www.jstor.org/stable/640395

[10] De la Garza, E. (2009). El Trabajo no clásico y la ampliación de los conceptos de producción, control, relación laboral y mercado de trabajo. Sociología del Trabajo 67, 71-95.

[11] Del Bono, A. (2010). La geografía de los call centers: territorio, trabajo y empleo. in S. Rotiman, P. Lisdero, And L. Marengo (ed.). La llamada... El trabajo y los trabajadores de Calls Centers en Córdoba (67-96). Córdoba, Argentina: Universitas.

[12] Del Bono, A. and Bulloni, M. N. (2008). Experiencias laborales juveniles. Los agentes telefónicos de call centers offshore en Argentina. Trabajo y Sociedad, 10, 01-21. Retrieved from: http://dialnet.unirioja.es/descarga/articulo/2565764.pdf

[13] Del Bono, A. and Henry, L. (2008). La acción sindical en el marco de las formas globalizadas de producción. Reflexiones a partir de la expansión de los calls center de servicios para exportación en Argentina. Revista Latinoamericana de Estudios Del Trabajo, II Época, Año 13, 20, 7-31. Retrieved from: http://dialnet.unirioja.es/descarga/articulo/2565764.pdf

[14] Fajn, J (2002). Cooperativa de Recuperadores de Residuos. Exclusión social y Autoorganización.
Cuaderno No2. Buenos Aires, Argentina: Ediciones del IMFC.

[15] Figari,C. and Alvarez Newman, D. (2011). Hegemonía empresarial y procesos de formación corporativos: la gestión por competencias y su certificación. Argentina: $10^{\circ}$ Congreso Nacional de Estudios del Trabajo.

[16] Gallard, M. and Jacinto, C. (1995). Competencias laborales: Tema clave en la articulación educación trabajo. Boletín Educación y Trabajo, 2, 83-92. Retrieved from: http://ecaths1.s3.amazonaws.com/unrnrrhh/1663493913 .Gallart\%200IT.pdf

[17] Goffman, E. (1970). Ritual de la interacción. Buenos Aires, Argentina: Ed. Tiempo Contemporáneo.

[18] Gross, J. J. and Feldman Barrett, L. (2011). Emotion generation and emotion regulation: one or two depends on your point of view. Emotion Review, vol.3, 1, 8-16. doi: $10.1177 / 1754073910380974$

[19] Hochschild, A. R. (1990). Ideology and emotion management: a perspective and path for future research. In T.D. Kemper (ed.), Research Agenda in the Sociology of Emotions (117-142). .New York, U.S.A.: University of New York Press.

[20] Katz, C. (2001). Desequilibrios y antagonismos de la Mundialización. Realidad Económica, 178, 90-121.

[21] Kemper, T. D. (1987). How Many Emotions Are There? Wedding the Social and the Autonomic Components..AJS - American Journal of Sociology, v. 93, n. 2, 263-289. Retrieved from: http://www.jstor.org/stable/2779585

[22] Lisdero, P. (2010). Call Centers: Comunicación, Tecnología y Trabajo. Hacia una propuesta interpretativa de las expropiaciones de las energías corporales en contextos de Neo-Colonialidad. In S. Roitman, P, Lisdero, and L. Marengo (ed.). La llamada... El Trabajo y los trabajadores de Call Centers en Córdoba (67-96). Córdoba, Argentina: Universitas Editorial Científica Universitaria.

[23] Lisdero, P. and Quatrini, D. (2013). Educación, corporalidad y nueva morfología del trabajo. Los Calls Centers ¿escuelas de trabajo?. Intersticios. Revista Sociológica de Pensamiento Crítico, Vol 7, $\mathrm{N}^{\circ} 1$ : 155 $172 . \quad$ Retrieved from: http://www.intersticios.es/article/download/10572/7775

[24] Lisdero, P. and Vergara, G. (2010). Promesas y desencantos de los nuevos trabajos. Un análisis de los mecanismos de sujeción en los recuperadores de residuos. Pensamento Plural, Vol. 1, n.6, 97-121. Retrieved

from: http://periodicos.ufpel.edu.br/ojs2/index.php/pensament oplural/article/view/3657/2993

[25] Micheli, J. T. (2007). Los call centers y los nuevos trabajos del siglo XXI. Revista Confines de relaciones internacionales y ciencia política, Vol. 3, N 5, 49-58.

[26] Montarcé, I. (2011). Del otro lado del teléfono: identidad y Acción Colectiva. In E. De La Garza (Ed.), 
Trabajo no clásico, organización y acción colectiva. Tomo II (69-122). Ciudad de México, México: Plaza y Valdés Editores.

[27] Montes Cató, J. (2006). Dominación y resistencias en los espacios de trabajo. Estudio sobre las relaciones de trabajo en empresas de telecomunicaciones. Buenos Aires, Argentina: Tesis Doctorado en Ciencias Sociales - UBA.

[28] Mulholland, K. (2002). Gender, emotional labour and teamworking in a call center. Personnel Review, Vol. 31,Iss: $\quad 3$ : 283-303. http://dx.doi.org/10.1108/00483480210422714

[29] Oliveira, S. M. (2009). Os trabalhadores das Centrais de teleatividades no Brasil: da ilusão à exploração. In R. Antunes and R. Braga (ed.). Infoproletários: degradação real do trabalho virtual (113-135). São Paulo, Brasil: Editorial Boitempo.

[30] Panaia, M. (2008). Sociología del riesgo. Accidentes de trabajo en el sector informal.Buenos Aires-Madrid, Argentina-España: Editorial Miño y Dávila.

[31] Perelman, M. (2014). Mundos del trabajo, identidades y prácticas. Trabajo y Sociedad, num.23, 45-65.

[32] Riquelme, G. and Herger, N. (2007). Las experiencias de reconocimiento de saberes de los trabajadores: entre la presión de las competencias y el desafío de la apropiación de saberes. Buenos Aires, Argentina: $8^{\circ}$ Congreso Nacional de Estudios del Trabajo. ASET.

[33] Scheff, T. J. (2001). Três pioneiros na sociologia das emoções. Política \& Trabalho 17, 115-127. Retrieved from:

http://www.biblionline.ufpb.br/ojs/index.php/politicaetr abalho/article/view/6485/4050

[34] Scribano, A. (2005).Geometría del conflicto: estudios sobre acción colectiva y conflicto social. Córdoba, Argentina: Universitas.

[35] __ 2007a. Mapeando interiores. Cuerpo, conflicto y sensaciones. Córdoba, Argentina: Sarmiento Editor.

[36] _ 2007b. Policromia corporal. Cuerpos, Grafías y Sociedad. Córdoba, Argentina: Sarmiento Editor.

[37] ___ (2010). Primero hay que saber sufrir ...!!! Hacia una Sociología de la 'espera' como mecanismo de soportabilidad social. In A. Scribano and P., Lisdero (ed.). Sensibilidades en juego: miradas múltiples desde los estudios sociales de los cuerpos y las emociones (169-192). Córdoba, Argentina: CEA-UNC-CONICET.

[38] _. (2012 a $)$. Sociología de los cuerpos/emociones. RELACES, 10, 93-113. Retrieved from: http://relaces.com.ar/index.php/relaces/article/view/224/ 143

[39] __ (2012b). Teorías sociales del Sur: Una mirada post-independentista. Buenos Aires, Argentina: ESEditora.

[40] Scribano, A. and Lisdero, P. (2009)."Trabajo, intercambios recíprocos y prácticas intersticiales". Política \& Trabajo, 31: 213-230. Retrieved from: http://www.ies.ufpb.br/ojs/index.php/politicaetrabalho/a rticle/view/6829/4264

[41] Smith, H. and Schneider, A. (2009). Critiquing models of emotions. Sociological Methods \& Research, vol. 37, n.4; 560-589. doi: 10.1177/0049124109335790

[42] Taylor, S. \& Bogdan, R. (1994). Introducción a los métodos cualitativos de investigación. Barcelona, España: Paidos.

[43] Vergara, G. (2012). Experiencias de la doble jornada en mujeres recuperadoras de residuos de Córdoba en la actualidad. Un análisis de sus tramas corporales, percepciones y emociones. Buenos Aires, Argentina: Tesis de doctorado en Ciencias Sociales, Universidad de Buenos Aires (inédito).

[44] Villanova, N. (2012) ¿Excluidos o incluidos?: Recuperadores de materiales reciclables en Latinoamérica. Revista Mexicana de Sociología, vol.74, n.2, 245-274. Retrieved from: http://www.scielo.org.mx/pdf/rms/v74n2/v74n2a3.pdf

\section{ADDITIONAL REFERENCES:}

[45] CINTEFOR - OIT. (1996). Boletín técnico iberoamericano de formación profesional. CINTEFOR/OIT N¹37. Montevideo.

[46] CINTEFOR - OIT. (2006) La nueva Recomendación 195 de OIT. Desarrollo de los recursos humanos: educación, formación y aprendizaje permanente. CINTERFOR/OIT. Montevideo

[47] Fundación Chile. (2005) Competencias Laborales para Chile 1999 - 2004. Memoria del programa de certificación de competencias laborales. Santiago. Chile.

[48] Fundación Chile.(2006). Perfiles de Competencias Directivas, Docentes y Profesionales de apoyo. Programa Educación y de Gestión Escolar de La Fundación Chile. Santiago.

[49] Grupo Tel (2011). Proyecto de Investigación y Capacitación en Salud Laboral,Salud y Condiciones de trabajo en el sector docente: diagnóstico y respuestas posibles. Informe final provisorio Marzo de 2011. . Retrieved from: http://www.tel.org.ar/spip/salud/icademystel.pdf

[50] Programa CEA - OIT (2011); Más y mejor trabajo para todos. Del Programa Jefes de Hogar al Programa Jóvenes. Políticas activas de empleo, Argentina 20032010. Programa CEA-OIT. 1a ed. Buenos Aires. 